\title{
Perbedaan Gender pada Kesadaran Metakognitif dalam Strategi Membaca Bacaan Akademik
}

\section{Gender Differences in Metacognitive Awareness of Academic Reading Strategies}

\author{
Wulansari Ardianingsih dan Rose Mini Agoes Salim \\ Departemen Psikologi Pendidikan \\ Fakultas Psikologi Universitas Indonesia, Depok
}

\begin{abstract}
Metacognitive awareness of reading strategies can be defined as the knowledge or awareness about strategies to process reading materials, the ability to monitor comprehension, and the ability to employ strategies in understanding text. Previous studies show inconsistent results regarding the role of gender in the metacognitive awareness of reading. The current study aims to evaluate gender differences in the students' knowlegde of metacognitive strategies in reading. This study involves 137 students (59 boys and 78 girls) from grade 4 to 6 . The current study uses Metacognitive Awareness of Reading Strategies Inventory (MARSI) that consists of 3 subscales: global strategy, problem solving, and support strategy. Results show that female students outperform male students in their metacognitive awareness, both in general scale and in each type of strategy. In addition, the most used strategy is the problem solving strategy, while the least used is the support strategy. This finding suggests that teachers need to consider the gender difference in determining the effective methods of delivering materials in classrooms.
\end{abstract}

Keywords: metacognitive awareness, reading, gender differences

\begin{abstract}
Abstrak: Kesadaran metakognitif dalam membaca dapat didefinisikan sebagai pengetahuan akan strategi untuk memproses bacaan, kemampuan untuk memonitor pemahaman, dan kemampuan untuk mengatur strategi yang dibutuhkan untuk memahami bacaan. Hingga saat ini masih terdapat hasil yang tidak konsisten mengenai peran gender dalam kesadaran metakognitif siswa. Penelitian ini bertujuan untuk menelaah lebih dalam mengenai bagaimana perbedaan siswa laki-laki dan perempuan pada kesadaran metakogntifnya dalam membaca, khususnya pada bacaan akademik. Penelitian melibatkan 137 siswa (59 laki-laki dan 78 perempuan) kelas 4 6 Sekolah Dasar (SD) dengan menggunakan alat ukur Metacognitive Awareness of Reading Strategies Inventory (MARSI) yang terdiri atas 3 dimensi: strategi global, penyelesaian masalah, dan strategi pendukung. Hasil penelitian menunjukkan bahwa siswa perempuan lebih sering menggunakan strategi meta-kognitif dibandingkan siswa laki-laki, baik secara keseluruhan maupun pada masing-masing jenis strategi. Selanjutnya, jenis strategi yang paling banyak dipakai adalah strategi penyelesaian masalah, sedangkan strategi yang paling jarang dipakai adalah strategi pendukung bacaan. Hasil penelitian ini berimplikasi pada kebutuhan guru untuk memperhatikan perbedaan gender siswa ketika menentukan metode penyampaian tugas atau materi belajar agar pembelajaran berlangsung efektif.
\end{abstract}

Kata kunci: kesadaran metakognitif, membaca, perbedaan gender

Korespondensi tentang artikel ini dapat dialamatkan kepada Wulansari Ardianingsih melalui e-mail: wulansari.a@gmail.com 
Penilaian Organisation for Economic Co-operation and Development (OECD) pada tahun 2015 terkait Programme for International Student Assesment (PISA) menunjukkan bahwa siswa Indonesia memiliki performa yang rendah pada tes pemahaman bacaan, yaitu menempati posisi ke 66 dari 72 negara (OECD, 2018). Hasil penilaian OECD cukup mengkhawatirkan mengingat kemampuan membaca merupakan salah satu kemampuan dasar yang penting dimiliki oleh siswa dan dibutuhkan pada hampir seluruh kegiatan akademik. Begum dan Hamzah (2017) menyatakan bahwa membaca merupakan kemampuan yang sangat penting dan dapat menentukan keberhasilan seorang siswa di sekolah. Peneliti lain, Cimmiyoti (2013), menemukan bahwa terdapat hubungan yang signifikan antara kemampuan membaca siswa Sekolah Dasar (SD) dengan kemampuan matematikanya. Sejalan dengan temuan tersebut, penelitian pada siswa sekolah menengah juga menunjukkan adanya hubungan antara kemampuan pemahaman bacaan siswa dan performa mereka pada pelajaran sains dan matematika (Akbasli, Sahin, \&Yaykiran, 2016).

Membaca merupakan sebuah proses yang kompleks dan melibatkan beberapa komponen. Menurut Gough dan Tunmer (Seperti dikutip dalam Melby-Lervag \& Lervag, 2014), kemampuan membaca terdiri atas dua komponen, yaitu kemampuan decoding dan kemampuan untuk memahami konten linguistik. Kemampuan decoding adalah kemampuan untuk mengubah informasi tulisan ke dalam bentuk suara. Salah satu komponen dari proses decoding adalah kelancaran membaca, yang merujuk pada kecepatan, ketepatan, dan ketepatan ekspresi ketika membaca. Pemahaman linguistik merupakan kemampuan untuk memahami makna semantik dari sebuah bahasa yang mencakup kemampuan untuk memahami arti kata, tata bahasa, penarikan kesimpulan, dan pemahaman naratif (Melby-Lervag \& Lervag, 2014). Pada perkembangannya, banyak peneliti juga menambahkan aspek kognitif umum dalam menggambarkan aspek kemampuan membaca, misalnya kemampuan dalam working memory dan pemrosesan auditori. Sejalan dengan hal tersebut, terdapat tiga aspek dalam proses membaca (Kolic-Vehovec, Bajsanski, \& Zubkovic, 2010). Aspek pertama adalah proses leksikal untuk pengenalan kata dan post-leksikal proses untuk memahami kata, kalimat, dan teks. Aspek kedua melibatkan kemampuan mempertahankan perhatian dan working memory, sedangkan aspek ketiga adalah komponen metakognisi dalam membaca. Komponen metakognisi dalam membaca melibatkan pengetahuan akan proses metakognisi dan strategi metakognisi yang diterapkan selama membaca. Kemampuan metakognisi tersebut muncul dalam bentuk penyusunan rencana, monitoring, dan evaluasi kegiatan membaca atau penggunaan strategi metakognitif yang digunakan untuk meningkatkan pemahaman bacaan.

Kemampuan metakognitif didefinisikan oleh Flavell (Seperti kutip dalam Varga, 2016) sebagai pemahaman seseorang tentang proses berpikir, hasil berpikir, dan berbagai hal yang berkaitan dengan proses berpikirnya. Secara sederhana, dapat disimpulkan bahwa metakognisi adalah proses berpikir tentang berpikir. Menurut Pintrich, Woltes, dan Baxter (2000), kemampuan metakognitif melibatkan tiga aspek, yaitu pengetahuan atau kesadaran tentang metakognisi, pemantauan metakognitif, dan regulasi diri. Menurut Auerbach dan Paxton (1997), kesadaran metakognitif dalam membaca adalah pengetahuan akan strategi untuk memproses bacaan, kemampuan untuk memonitor pemahaman, dan kemampuan untuk mengatur strategi yang dibutuhkan untuk memahami bacaan.

Berbagai penelitian di bidang metakognisi menunjukkan bahwa kemampuan metakognisi merupakan kemampuan yang bersifat umum. Akan tetapi, perkembangan penelitian menunjukkan bahwa kemampuan metakognitif merupakan kemampuan 
yang diterapkan secara spesifik pada domain-domain tertentu (Kolic-Vehovec, Bajsanski, \& Zubkovic, 2010). Penelitian tersebut kemudian menyimpulkan bahwa kemampuan metakognisi pada awalnya berkembang pada domain yang berbeda, kemudian menjadi sebuah kemampuan yang terintegrasi dan dapat diterapkan di tugas-tugas kognitif yang berbeda, termasuk dalam membaca.

Berbagai penelitian telah menunjukkan bahwa kemampuan metakognitif anak memiliki hubungan dengan pemahaman bacaan anak (Kolic-Vehovec \& Bajsanski, 2006). Siswa yang memiliki kemampuan metakognitif yang tinggi mampu memahami bacaan dengan lebih baik. Sejalan dengan hal tersebut, siswa-siswa yang memiliki hambatan dalam membaca juga menunjukkan kemampuan metakognitif yang rendah.

Kemampuan metakognitif dalam membaca berkembang seiring dengan bertambahnya usia anak. Sebelum anak memasuki usia sekolah, anak mulai mengembangkan kesadaran akan bacaan melalui berbagai stimulus yang diterima dari lingkungan (Kolic-Vehovec et al., 2010). Pada usia 8 sampai 10 tahun, kemampuan metakognitif dalam membaca mulai berkembang. Kolic-Vehovec et al. (2010) menyatakan bahwa pengetahuan metakognitif pada anak usia 8 sampai 12 tahun menunjukkan perbedaan dimana anak yang lebih tua memiliki pengetahuan yang lebih baik tentang struktur bacaan, berbagai tujuan membaca, dan strategi membaca. Kemampuan metakognitif anak tersebut semakin meningkat pada jenjang pendidikan menengah (Kolic-Vehovec et al., 2010).

Selain itu, beberapa aktivitas metakognitif muncul lebih lambat dari strategi lainnya, misalnya aktivitas monitoring dan evaluasi. Seiring semakin berkembangnya usia anak, kemampuan metakognitif dalam membaca lebih terfokus pada kemampuan akademik. Kemampuan metakognitif tersebut berkembang sampai individu berada pada jenjang perkuliahan di perguruan tinggi (Kolic-Vehovec et al., 2010).

Pada perkembangannya, berbagai penelitian mengenai kesadaran metakognitif dalam membaca mulai fokus pada bacaan yang bersifat akademik. Mokhtari dan Reichard (2002) secara spesifik meneliti tentang pengetahuan metakognisi dalam membaca pada teks akademik. Hasilnya, mereka menemukan ada tiga jenis strategi, yaitu strategi global, strategi penyelesaian masalah, dan strategi pendukung bacaan.

Strategi global merupakan salah satu strategi membaca yang berorientasi pada analisis teks secara global. Melalui strategi ini, siswa melakukan generalisasi terhadap pemahaman teks. Strategi global yang dapat digunakan siswa antara lain melakukan preview atau membaca sepintas teks sebelum membaca atau mengatur harapan selama membaca.

Strategi penyelesaian masalah adalah strategi untuk menyelesaikan tantangan saat bacaan menjadi semakin sulit. Strategi jenis ini mencakup antara lain membaca secara perlahan dan berhati-hati, mengatur kecepatan membaca tergantung jenis bacaan, membaca ulang, membayangkan suatu kata, atau menebak makna dari sebuah kata.

Selanjutnya, strategi pendukung bacaan merupakan strategi yang digunakan untuk memahami bacaan melalui bantuan tambahan, misalnya dengan mencari referensi dari luar atau dengan membuat catatan. Bantuan lain yang dapat digunakan antara lain dengan memanfaatkan kamus untuk membantu mengetahui pemahaman arti kata (Mokhtari \& Reichard, 2002).

Beberapa tahun terakhir, penelitian mengenai kesadaran metakognitif mulai banyak melihat apakah terdapat perbedaan di antara siswa laki-laki dan perempuan dalam hal kesadaran metakognitif dalam membaca. Penelitian-penelitian tersebut menunjukkan berbagai hasil yang tidak konsisten. Kolic-Vehovec dan Bajsanski (2006) menemukan bahwa siswa perempuan menunjukkan kemampuan pemaha- 
man bacaan yang lebih tinggi dibandingkan dengan siswa laki-laki. Selain itu, siswa perempuan juga menggunakan strategi metakognitif yang lebih banyak dibandingkan dengan siswa laki-laki. Sejalan dengan hal tersebut, beberapa penelitian lain juga menyimpulkan bahwa mahaiswa perempuan lebih banyak menggunakan kesadaran metakognitif daripada laki-laki dalam menyelesaikan tugas bacaan (Alami, 2016; Li, 2010; Velool, Rani, \& Hariharan, 2015).

Di sisi lain, Abu-Snoubar (2017) menemukan bahwa tidak terdapat perbedaan yang signifikan antara siswa laki-laki dan perempuan dalam hal strategi metakognitifnya. Penelitian lain (Misu \& Masi, 2017) juga menujukkan bahwa tidak ada perbedaan signifikan antara mahasiswa laki-laki dan perempuan dalam kesadaran metakognitif pada matematika.

Hasil yang tidak konsisten ini menunjukkan bahwa peran gender dalam kesadaran metakognitif masih butuh ditelaah lebih dalam. Oleh karena itu, penelitian ini bertujuan untuk mengetahui apakah terdapat perbedaan antara siswa laki-laki dan perempuan dalam kesadaran meta-kognitifnya akan strategi membaca bacaan akademik. Hipotesis penelitian ini adalah terdapat perbedaan yang signifikan antara siswa perempuan dan laki-laki dalam hal kesadaran metakognitif akan strategi membaca bacaan akademik.

\section{Metode}

\section{Partisipan}

Partisipan penelitian ini adalah siswa kelas $4-6$ di salah satu SD di Jakarta. Pemilihan sampel dilakukan menggunakan teknik non-probability sampling, tepatnya accidental sampling. Penggunaan metode sampling ini dipilih untuk memudahkan peneliti mendapatkan partisipan penelitian.

Terdapat 151 Siswa yang mengikuti penelitian ini. Akan tetapi, hanya 137 data yang dapat digunakan dan sebanyak 14 data tidak dapat diolah karena adanya pengisian data yang tidak lengkap. Jumlah siswa laki-laki adalah sebanyak 59 orang dan siswa perempuan sebanyak 78 orang. Partisipan terdiri atas siswa kelas 4 (49.6\%), siswa kelas 5 (20.4\%), dan siswa kelas $6(29.9 \%)$ yang berusia antara 9 sampai dengan 12 tahun ( $\mathrm{M}=10.42$ tahun).

Penelitian ini telah mendapat persetujuan dari komite kaji etik Fakultas Psikologi, Universitas Indonesia. Sebelum penelitian dimulai, orang tua partisipan diberikan surat ijin secara tertulis. Selain itu, siswa juga ditanyakan kesediaannya secara lisan di awal sesi penelitian. Siswa yang mendapat ijin dari orang tua atau tidak bersedia diperkenankan untuk tidak mengikuti penelitian ini.

\section{Pengumpulan Data}

Pengambilan data dilakukan dengan menyebar kuesioner yang berisikan data demografis dan alat ukur MARSI. Partisipan mengisi kuesioner secara mandiri. Di akhir pengisian kuesioner, peneliti memberikan lembar debriefing berisikan tentang strategi metakognitif dalam membaca yang dapat diterapkan oleh para partisipan untuk membantu memahami bacaan.

Penelitian ini menggunakan alat ukur Metacognitive Awareness of Reading Strategies Inventory (MARSI) yang dikembangkan oleh Mokhtari dan Reichard (2002). Alat ukur ini mengukur seberapa baik seorang anak mengenali penggunaan strategi membacanya. MARSI terdiri atas 3 dimensi, yaitu: strategi membaca umum (13 aitem), strategi penyelesaian masalah (8 aitem), dan strategi pendukung (berjumlah 9 aitem). Jumlah total aitem pada alat ukur ini adalah sebanyak 30 buah. Pengukuran dilakukan menggunakan skala likert dengan 5 pilihan jawaban $(1=$ tidak pernah atau hampir tidak pernah, $2=$ jarang, 3 = kadang-kadang, 4 = sering, dan 5 = selalu atau hampir selalu). Untuk memudahkan interpretasi perbandingan skor antar dimensi, skor dirata-rata dan di- 
kategorikan menggunakan hypotetical mean. Kategori skor dapat dilihat pada tabel 1.

Tabel 1. Kategori Skoring

\begin{tabular}{lc}
\hline Kategori & Rentang Skor \\
\hline Rendah & $1-2.2$ \\
Sedang & $2.3-3.6$ \\
Tinggi & $3.7-5$ \\
\hline
\end{tabular}

Alat ukur ini telah diadaptasi ke dalam Bahasa Indonesia oleh peneliti. Proses validasi melibatkan tahap alih bahasa atau penerjemahan, uji keterbacaan, dan uji reliabilitas. Uji keterbacaan melibatkan 4 orang siswa SD kelas $4-5$ dan uji reliabilitas melibatkan 53 siswa SD kelas $4-5$. Hasil uji reliabilitas menunjukkan bahwa alat ukur ini memiliki reliabilitas yang baik, dengan skor $\alpha=0.88$ untuk keseluruhan alat ukur, serta untuk masing-masing dimensi sebesar $\alpha=0.78$ untuk dimensi strategi global, $\alpha=0.77$ untuk dimensi penyelesaian masalah, dan $\alpha=0.60$ untuk dimensi strategi pendukung.

Pada tahap pengambilan data penelitian, alat ukur ini memiliki skor reliabilitas $\alpha=0.90$ untuk keseluruhan alat ukur; $\alpha=$ 0.80 untuk dimensi strategi global; $\alpha=$ 0.76 untuk dimensi penyelesaian masalah, dan $\alpha=0.71$ untuk dimensi strategi pendukung. Hasil ini menunjukkan bahwa aitem-aitem dalam alat ukur ini konsisten dalam mengukur 1 konstruk yang sama.

\section{Analisis Data}

Analisis data dilakukan dengan menggunakan beberapa teknik statistik. Untuk mengolah gambaran umum partisipan dan data mengenai strategi metakognitif dalam membaca peneliti menggunakan teknik statistik deskriptif. Selanjutnya, untuk menganalisis perbedaan gender dalam strategi membaca, peneliti menggunakan teknik statistik Mann Whitney-U. Teknik statistik ini merupakan teknik non-parametrik dari t-test. Peneliti menggunakan teknik statistik non-parametrik karena jumlah partisipan laki-laki dan perempuan tidak seimbang.

\section{Hasil}

Berdasarkan hasil analisis data, diketahui bahwa secara umum partisipan penelitian memiliki kesadaran metakognitif akan strategi membaca yang masuk dalam kategori sedang. Strategi metakognitif dalam membaca yang paling banyak digunakan adalah yang berkaitan dengan penyelesaian masalah dan strategi yang paling jarang digunakan adalah strategi pendukung bacaan (lihat Tabel 2.)

Tabel 2. Gambaran umum variabel

\begin{tabular}{lcccc}
\hline \multicolumn{1}{c}{ Dimensi } & M & SD & Min & Max \\
\hline Total Skor & 3.29 & 0.62 & 1.37 & 4.97 \\
$\begin{array}{l}\text { Strategi } \\
\text { global }\end{array}$ & 3.26 & 0.67 & 1.15 & 5 \\
$\begin{array}{l}\text { Penyelesaian } \\
\text { Masalah }\end{array}$ & 3.72 & 0.69 & 1.75 & 5 \\
$\begin{array}{l}\text { Strategi } \\
\text { Pendukung }\end{array}$ & 2.96 & 0.69 & 1 & 4.89 \\
\hline
\end{tabular}

Hasil analisis data menunjukkan bahwa secara keseluruhan (berdasarkan skor total), terdapat $68.61 \%$ partisipan berada pada kategori sedang, $27.74 \%$ pada kategori tinggi, dan $3.65 \%$ pada kategori rendah. Selanjutnya, ditelaah berdasarkan dimensi atau jenis strategi yang digunakan, untuk strategi membaca umum $71.53 \%$ partisipan berada pada kategori sedang, $23.36 \%$ pada kategori tinggi, dan $5.12 \%$ pada kategori rendah. Pada strategi penyelesaian masalah, $56.93 \%$ siswa berada pada kategori tinggi, $39.42 \%$ pada kategori sedang, dan $3.65 \%$ pada kategori rendah. Berikutnya, pada strategi membaca pendukung, $73.72 \%$ partisipan berada pada kategori sedang, $12.41 \%$ pada kategori tinggi, dan $13.87 \%$ pada kategori rendah.

\section{Peran Gender pada Strategi Membaca}

Berikut ini adalah perbandingan hasil pengukuran pada siswa laki-laki dan siswa 
perempuan. Dapat dilihat pada Tabel 3 bahwa baik secara total maupun pada masing-masing jenis strategi, siswa perempuan selalu mendapatkan skor yang lebih tinggi dibandingan dengan siswa laki-laki. Secara umum, sebagian besar partisipan berada pada kategori sedang.

Tabel 3. Rata-rata Skor Partisipan

\begin{tabular}{lcc}
\hline \multicolumn{1}{c}{ Dimensi } & $\mathrm{M}_{\text {Laki-laki }}$ & $\mathrm{M}_{\text {Perempuan }}$ \\
\hline Skor Total & 3.09 & 3.45 \\
Strategi global & 3.06 & 3.42 \\
$\begin{array}{l}\text { Penyelesaian } \\
\text { Masalah }\end{array}$ & 3.50 & 3.88 \\
$\begin{array}{l}\text { Strategi } \\
\text { Pendukung }\end{array}$ & 2.76 & 3.12 \\
\hline
\end{tabular}

Hal yang berbeda tampak pada strategi penyelesaian masalah, yaitu sebagian besar partisipan berada pada kategori tinggi, khususnya pada partisipan perempuan. Gambaran peserta berdasarkan kategori penggunaan strategi dapat dilihat pada Tabel 4.

Tabel 4. Persentase Partisipan pada Masingmasing Kategori

\begin{tabular}{lccc}
\hline & \multicolumn{3}{c}{ Strategi global } \\
\hline Jenis Kelamin & Rendah & Sedang & Tinggi \\
Perempuan & $1.46 \%$ & $39.42 \%$ & $16.06 \%$ \\
Laki-Laki & $3.65 \%$ & $32.12 \%$ & $7.30 \%$ \\
\hline \multicolumn{4}{c}{ Strategi Penyelesaian } \\
\multicolumn{4}{c}{ Masalah } \\
\hline Jenis Kelamin & Rendah & Sedang & Tinggi \\
Perempuan & $0.73 \%$ & $16.79 \%$ & $39.42 \%$ \\
Laki-Laki & $2.92 \%$ & $22.63 \%$ & $17.52 \%$ \\
\hline \multicolumn{4}{c}{ Strategi Pendukung } \\
\hline Jenis Kelamin & Rendah & Sedang & Tinggi \\
Perempuan & $2.92 \%$ & $44.53 \%$ & $9.49 \%$ \\
Laki-Laki & $10.95 \%$ & $29.20 \%$ & $2.92 \%$ \\
\hline
\end{tabular}

Berdasarkan hasil uji statistik menggunakan Mann-Whitney U-test, diketahui bahwa terdapat perbedaan yang signifikan antara jenis kelamin dan kesadaran metakognitif akan strategi membaca secara keseluruhan $(\mathrm{U}=1556.5, \mathrm{p}=0.001)$. Selanjutnya, terdapat pula perbedaan yang signifikan antara siswa laki-laki dan perempuan pada penggunaan masing-masing jenis strategi membaca. Hasil pengujian berdasarkan masing-masing jenis strategi membaca dapat dilihat pada Tabel 5.

Tabel 5. Hasil Uji Statistik

\begin{tabular}{lcc}
\hline \multicolumn{1}{c}{ Dimensi } & $\mathrm{U}$ & $\mathrm{p}$ \\
\hline $\begin{array}{l}\text { Strategi } \\
\text { global }\end{array}$ & 1625 & $0.003^{*}$ \\
$\begin{array}{l}\text { Penyelesaian } \\
\text { Masalah }\end{array}$ & 1513.5 & $0.001^{*}$ \\
$\begin{array}{l}\text { Strategi } \\
\text { Pendukung }\end{array}$ & 1676.5 & $0.007^{*}$ \\
\hline
\end{tabular}

\section{Pembahasan}

Penelitian ini bertujuan untuk menguji apakah terdapat peran gender dalam kesadaran metakognitif akan strategi membaca. Penelitian ini menemukan bahwa terdapat perbedaan yang signifikan antara siswa laki-laki dan perempuan dalam hal kesadaran metakognitif dalam membaca. Hasil ini sejalan dengan penelitian Liliana dan Lavinia (2011) yang juga menunjukkan adanya perbedaan kesadaran metakognisi pada laki-laki dan perempuan.

Secara spesifik penelitian kali ini juga menemukan bahwa siswa perempuan cenderung lebih sering dalam menggunakan strategi metakognitif dalam membaca. Temuan ini sejalan dengan penelitian sebelumnya yang juga menemukan bahwa siswa perempuan menunjukkan performa yang lebih baik dalam berbagai aspek membaca. Penelitian Veloo et al. (2014) mengenai kesadaran metakognitif pada mahasiswa menyimpulkan bahwa mahasiswa perempuan cenderung lebih sering menggunakan strategi metakognitif dalam membaca bacaan akademik. Selain itu, penelitian Logan dan Johnston (2009) menyimpulkan bahwa siswa perempuan memiliki kemampuan pemahaman bacaan yang lebih baik dibandingkan dengan siswa laki-laki. Selain itu, siswa perem- 
puan memiliki sikap yang lebih baik terhadap membaca serta lebih sering melakukan aktivitas membaca. Karena itu, para siswa perempuan memiliki kesempatan yang lebih sering untuk menerapkan strategi metakognitif saat membaca.

Berbeda dengan penelitian sebelumnya yang lebih banyak membahas tentang kesadaran metakognitif pada mahasiswa (Abu-Snoubar, 2017; Misu \& Masi, 2017; Veloo et al., 2015), penelitian ini melibatkan siswa pada sekolah dasar. Meskipun demikian, penelitian ini memeroleh hasil yang sama dengan penelitian sebelumnya, bahwa siswa secara umum sadar akan strategi metakognitifnya dalam membaca. Hal ini sejalan dengan apa yang disampaikan oleh Kolic-Vehovec et al. (2010) bahwa kesadaran metakognitif mulai berkembang pada usia $8-10$ tahun. Karena itu, siswa-siswa kelas $4-6$ SD cenderung sudah mengembangkan kesadaran metakognitif.

Jika ditelaah berdasarkan jenis strateginya, ditemukan bahwa jenis strategi yang digunakan oleh siswa perempuan dan siswa laki-laki relatif sama. Baik siswa perempuan maupun siswa laki-laki samasama paling banyak menggunakan strategi penyelesaian masalah dan paling jarang menggunakan strategi pendukung. Dalam hal jenis strategi yang digunakan, hasil tersebut sejalan dengan beberapa penelitian sebelumnya, misalnya yang dilakukan oleh Abu-Snoubar (2017) serta Mokhtari dan Riechard (2002).

Jika dilihat dari jenis teks, bacaan akademik dapat digolongkan ke dalam jenis teks ekspositori (Burton, 2008; Marzban \& Seifi, 2013). Jenis teks ini cenderung lebih sulit dibandingkan dengan jenis teks lain, yaitu teks narasi, karena memiliki struktur yang lebih beragam, mencakup kata-kata yang lebih sulit, dan biasanya tidak berkaitan dengan pengalaman pribadi (Williams, 2005). Karena itu, strategi penyelesaian masalah akan sangat membantu dalam memahami bacaan yang bersifat akademik. Misalnya, dengan membaca secara perlahan dan membaca berulang untuk mengetahui apa yang sedang dibaca, atau berusaha menebak arti dari kata yang sulit atau tidak diketahui (Mokhtari \& Riechard, 2002).

Pada penelitian ini, ditemukan bahwa pada masing-masing jenis strategi, siswa perempuan selalu menunjukkan skor yang lebih tinggi dibandingkan dengan siswa laki-laki. Hasil ini berbeda dengan penelitian Veloo et al. (2015) yang menemukan bahwa perbedaan gender hanya muncul pada jenis strategi penyelesaian masalah. Hasil pada penelitian ini juga berbeda dari penelitian Martinez dan Cristina (2008) yang hanya menemukan perbedaan gender pada jenis strategi pendukung bacaan.

Perbedaan hasil penelitian ini dapat diasumsikan dipengaruhi oleh perbedaan usia partisipan yang dilibatkan pada penelitian kali ini. Partisipan pada penelitian Veloo et al. (2014) serta Martinez dan Cristina (2008) adalah para mahasiswa di pergu-ruan tinggi, sedangkan para partisipan pada penelitian ini adalah siswa sekolah dasar. Penjelasannya adalah bahwa pada usia-usia sekolah dasar, perspesi perbedaan gender lebih kuat dibandingkan saat siswa sudah lebih dewasa.

Seperti yang ditemukan dalam penelitian Taylor, Rhodes, and Gelman (2009), anak-anak pada usia yang lebih muda cenderung memandang semua perbedaan antara laki-laki dan perempuan secara lebih esensialis daripada pada orang yang lebih dewasa. Artinya, anak-anak cenderung memandang semua perbedaan antara laki-laki dan perempuan baik secara fisik maupun sosial dan psikologis merupakan bawaan dan tidak dapat berubah.

Seperti disimpulkan oleh Igbo, Onu, dan Obiyo (2015), meskipun streotip gender tidak langsung memengaruhi kemampuan akademik anak dalam matematika, namun stereotip tersebut mempengaruhi cara anak mengevaluasi kemampuan akademiknya dalam matematika. Selanjutnya cara anak mengevaluasi kemampuan 
akademiknya berpengaruh terhadap pencapaian akademik aktualnya. Berdasarkan temuan tersebut, dapat diasumsikan adanya kaitan antara cara anak-anak mempersepsi perbedaan gender dengan kesadaran dan kemampuan metakognitifnya.

Perbedaan kemampuan dalam strategi metakognitif pada anak laki-laki dan perempuan ini tidak bersifat permanen. Seperti yang disampaikan oleh KolicVehovec et al. (2010), perkembangan kesadaran metakognitif anak akan terus berkembang dan semakin berfokus pada hal-hal akademik sampai anak masuk ke jenjang perkuliahan. Dalam hal ini, persepsi perbedaan gender yang juga berubah seiring usia anak dapat menentukan kondisi kemampuan metakognitif kedua gender ini pada usia yang semakin dewasa.

Terdapat beberapa limitasi dalam penelitian ini. Pertama, penelitian ini adalah penelitian cross-sectional sehingga tidak dapat melihat perkembangan kesadaran metakognitif secara lebih mendalam. Selain itu, penelitian ini hanya berfokus untuk menelaah kesadaran metakognitif pada siswa usia sekolah dasar sehingga belum dapat melihat bagaimana perbedaannya dengan siswa-siswa dari jenjang pendidikan yang lebih tinggi.

Selanjutnya, penelitian ini juga tidak menguji kekuatan perbedaan gender pada sudut pandang anak laki-laki dan anak perempuan dan kaitannya dengan perbedaan kesadaran dan kemampuan metakognitif mereka. Perbedaan persepsi terkait perbedaan gender pada kedua jenis kelamin ini penting dilakukan karena menurut penelitian Koenig (2018), anak dan remaja laki-laki cenderung memegang stereotip perbedaan gender yang lebih kaku daripada anak dan remaja perempuan. Perlu dilakukan penelitian terhadap perbedaan dalam stereotip gender ini terkait dengan pengaruhnya pada kemampuan akademik secara umum dan kemampuan metakognitif pada khususnya.

\section{Simpulan}

Hasil penelitian ini menyimpulkan bahwa terdapat perbedaan yang signifikan antara siswa SD laki-laki dan perempuan dalam hal kesadaran metakognitif dalam membaca bacaan akademik. Selain itu, subjek siswa SD, baik laki-laki maupun perempuan, paling banyak menggunakan jenis strategi penyelesaian masalah dalam memahami bacaan yang bersifat akademik. Namun, secara umum siswa perempuan lebih sering menggunakan strategi metakogntif dibandingkan siswa laki-laki. Para siswa perempuan juga lebih sering menggunakan masing-masing jenis strategi metakognitif dibandingan dengan siswa laki-laki. Terakhir, penelitian ini menyimpulkan bahwa skor anak perempuan lebih tinggi pada semua jenis kemampuan metakognitif dibanding anak laki-laki.

\section{Saran}

Hasil penelitian ini menunjukkan bahwa siswa laki-laki maupun perempuan paling banyak menggunakan strategi penyelesaian masalah, dan paling jarang menggunaan strategi pendukung bacaan. Karena itu, untuk dapat mengoptimalkan penggunaan strategi metakognitif siswa, guru dapat mendorong siswa untuk memperbanyak penggunaan strategi pendukung bacaan, misalnya dengan mendorong siswa untuk melihat referensi tambahan saat ada materi yang membingungkan di sekolah. Khusus untuk siswa laki-laki, guru dapat perlu lebih mendorong penggunaan strategi metakognitif dalam membaca bacaan akademik, misalnya dengan memberikan latihan secara khusus yang mengajarkan para siswa akan masing-masing strategi.

Selanjutnya, untuk mendapatkan gambaran yang lebih komprehensif tentang perkembangan kesadaran metakognitif individu, peneliti selanjutnya dapat melakukan penelitian longitudinal, dan 
menguji faktor individual lain yang mungkin memengaruhi kesadaran metakognitif, misalnya usia. Karena itu penting untuk melibatkan partisipan dari setiap jenjang pendidikan pada penelitian-penelitian selanjutnya.

\section{Daftar Pustaka}

Abu-Snoubar, T. K. (2017). Gender Differences in Metacognitive Reading Strategy Use among English as a Foreign Language Students at Al-Balqa Applied University. Journal of Education and Practice. $8(18), 1$ - 12. Retrieved from: https://www.iiste.org/Journals/index. php/JEP/article/view/37655

Akbasli, S., Sahin, M., \& Yaykiran, Z. (2016). The Effect of Reading Comprehension on the Performance in Science and Mathematics. Journal of Education and Practice, 7(16), 108-121. Retrieved from: https://www.iiste.org/Journals/index. php/JEP/article/view/31539

Alami, M. (2016). Cross-gender Comparison of Metacognitive Strategies Utilized by Omani Students in Reading Comprehension Classes. International Journal of Applied Linguistics \& English Literature, Vol. 5 No.4, 20 - 28. doi: http://dx.doi.org/10.7575/aiac.ijalel.v .5 n. 4 p. 20

Auerbach, E., \& Paxton, D. (1997). "It"s not the English thing": Bringing reading research into the ESL classroom. TESOL Quarterly, 31, 237-261. doi: 10.2307/3588046

Begum, F. U., \& Hamzah, M. H. (2017). Reading Comprehension Skills of Elementary School Students in Rural Area, Telanggana State: A Theoretical Approach. .Veda's Journal of English Language and Literature, 4(1), 12-17 Retrieved from: https://www.researchgate.net/publica tion/313443073 READING_COMPREH ENSION_SKILLS_OF_ELEMENTARY_S CHOOL_STUDENTS_IN_RURAL_AREA _TELANGANA_STATE_A_THEORETIC AL_APPROACH

Burton, R. C. (2008). Oral Retelling as a Measure of Reading Comprehension: The Generalizability of Ratings of Elementary School Students Reading Expository Texts. All Theses and Dissertations, 1678. Retrieved from: https://scholarsarchive.byu.edu/etd/1 678

Cimmiyotti, C. B. (2013). Impact of Reading Ability on Academic Performance at the Primary Level. Graduate Master's Theses, Capstones, and Culminating Projects. 127. doi: 10.33015/domi nican.edu/2013.edu.18

Igbo, J. N., Onu, V. C., \& Obiyo, N. O. (2015). Impact of gender stereotype on secondary school students' selfconcept and academic achievement. SAGE Open, 5(1), 110. doi: $10.1177 / 21582440155739$ 34

Koenig A. M. (2018). Comparing Prescriptive and Descriptive Gender Stereotypes About Children, Adults, and the Elderly. Frontiers in psychology, 9, 1086. doi:10.3389/fpsyg.2018.01086

Kolić-Vehovec, S., \& Bajšanski, I. (2006). Metacognitive strategies and reading comprehension in elementary-school students. European Journal of Psychology of Education, 21(4), 439-451 
Retrieved from: https://www. jstor.org/stable/23421392

Kolic-Vehovec, S., Bajsanski, I., \& Zubkovic, B. R. (2010). Metacognition and Reading Comprehension: Age and Gender Differences. In A. Efklides \& $\mathrm{P}$. Misailidi (Eds.). Trends and prospects in metacognition research. (pp. 327-344). New York: Springer.

Li, F. (2010). A Study of English Reading Strategies Used by Senior Middle School Students. Asian Social Science, 6(10), 184 - 192. Retrieved from http://citeseerx.ist.psu.edu/vie wdoc/download?doi=10.1.1.1009.51 $7 \&$ rep=rep1\&type $=$ pdf

Liliana, C., \& Lavinia, H. (2011). Gender Differences in Metacognitive Skills. A Study of the 8th Grade Pupils in Romania. Procedia - Social and Behavioral Sciences 29, 396-401. doi: 10.1016/j.sbspro.2011.11.255

Logan, S., \& Johnston, R.S. (2009). Gender differences in reading ability and attitudes: Examining where these differences lie. Journal of Research in Reading, 32(2), 199214. doi: 10.1111/j.14679817.2008.01389.x

Martinez, L. \& Cristina, A. (2008). Analysis of ESP University Students' Reading Strategy Awareness. Iberica, 15, 165-176. Retrieved from: http://www.reda lyc.org/pdf/2870/287024060010.pdf

Marzban, A., \& Seifi, S. (2013). The Effect of Genre Structure on Reading Comprehension Ability of Iranian EFL Learners. Procedia Social and Behavioral Sciences, 83, 1043-1048. doi: 10.1016/j.sbspro. 2013.06.194
Melby-Lervåg, M., \& Lervåg, A. (2014). Effects of Educational Interventions Targeting Reading Comprehension and Underlying Components. Child Development Perspectives, 8(2), 96-100. doi: 10.1111/cdep.12068

Misu, L. \& Masi, L. (2017). Comparison of Metacognition Awareness of Male and Female Students Based on Mathematics Ability in Department of Mathematics Education of Halu Oleo University. International Journal of Education and Research, 5(6), 43-50. Retrieved from: https://www.ijern.com/journal/2017/ June-2017/04.pdf

Mokhtari, K., \& Reichard, C. A. (2002). Assessing students' metacognitive awareness of reading strategies. Journal of Educational Psychology, 94(2), 249-259. doi: 10.1037/00220663.94.2.249

Pintrich, P., Wolters, C., \& Baxter, G. (2000). Assessing metacognition and self-regulated learning. In G. Schraw \& J. Impara (Eds.), Issues in the measurement of cognition ( $\mathrm{pp}$ 44-97). Lincoln, NE: Buros Institute of Mental Measurement.

Taylor, M. G., Rhodes, M., \& Gelman, S. A. (2009). Boys will be boys; cows will be cows: children's essentialist reasoning about gender categories and animal species. Child development, 80(2), 461-481. doi: 10.1111/j.1467-8624.2009.01272.x

Varga, A. (2017). Metacognitive perspectives on the development of reading comprehension: a classroom study of literary text-talks. Literacy, 51(1), 19-25. doi: 10.1111/lit.12095

Veloo1, A., Rani, M. A., \& Hariharan, K. (2015). The Role of Gender in the Use of Metacognitive Awareness Reading Strategies among Biology 
Students. Asian Social Science, 11(1), 67-73. Retrieved from: https://core.ac.uk/download/pdf/784 85760.pdf
Williams, J. P. (2005). Instruction in Reading Comprehension for Primary-Grade Students: A Focus on Text Structure. The Journal of Special Education, 39(1), 6-18. doi: $10.1177 / 00224669050390010201$ 